\title{
Unsaturated sand in the stability of the cuesta of the Temple of Hera (Agrigento)
}

\author{
N. Nocilla, L. Ercoli \& M. Zimbardo \\ University of Palermo, Italy
}

\author{
A. Nocilla \\ University of Brescia, Italy \\ P. Meli \\ Soprintendenza BB.CC.AA. di Agrigento, Italy \\ G. Grado, G. Parello \& G. Presti \\ Parco Archeologico e Paesaggistico della Valle dei Templi di Agrigento, Italy
}

\begin{abstract}
In the Valle dei Templi in Agrigento seven Doric temples stand lengthwise the crest of a rigid calcarenite cuesta over a layer of carbonate sand which lies along a thick stratum of clays. The environment is highly prone to landslides since topplings of calcarenite blocks often occur. The rock slopes are moving back and the slope edge draw near to the foundation of the Temple of Hera Lacinia contributing to increase their perilous condition. To assess the role of unsaturated sands in the instability processes, after the compositional and textural analysis of the material, direct shear tests and oedometer tests have been carried out on sand samples initially at the natural state, with low or very low values of natural water content, and finally at higher values of the saturation degree.

The mechanical behaviour of sands seems one of the main causes of the instability influenced by the presence of an open metastable structure, which develops through bonding mechanisms generated via suctions and/or through cementing material such as clay or salts.
\end{abstract}

\section{INTRODUCTION}

The Valle dei Templi in Agrigento (ancient Akragas) is one of the most outstanding examples of art and architecture in Magna Graecia. The Valley, which has been added in the UNESCO Heritage Site List, includes remains of seven temples, all in Doric style, that stand on the crest of a cuesta made of calcarenite overlaying a thin layer of sand, which overlies a stratum of clays. The environment is highly prone to landslides as highlighted by several previous studies that evidence both the role played by the discontinuity pattern in calcarenite and the role of the clays and sands in land forming processes (Croce et al., 1980, Cotecchia 1996). Cotecchia's work has also evidenced the role of earthquakes in the evolution of the territory, particularly from the point of view of the "human" landscape.

In 1976, on the E-NE slope close to the Temple of Hera Lacinia, a huge reactivated landslide occurred. This landslide, known and previously mentioned by Cavallari in his writing in 1883 , involved the whole outcropping stratigraphy, from the deep clays up to the calcarenite bench (Musso \& Ercoli 1988, Cotecchia et al., 1995). According to Cotecchia et al., the intense rainfall, which occurred just before the event, is the main cause of the landslide reactivation. This seems to be confirmed by the Royal Commission, presided over by the Prince Lanza di Scalea in 1883: although in the stratigraphy no sand layer is identiied, the stability of the cuesta, the Temple and its access route is influenced by the "softening" of the basal clay stratum and by the condition of the rock "calcareous tuff made of shells fragments" ("tufo calcare conchilifero") under the stratum, which "tends to disintegrate under mechanical and chemical actions". The Royal Commission indicated the erosion, caused by rainfalls and wind actions, as the origin of the instability and consequently arranged structural operations in order to limit erosion and further instabilities.

Nowadays, the mechanical behaviour of the sand layer seems to have a key role in the understanding of the mechanisms of instability. Several year long in situ observations and a laboratory experimental programme enabled the authors of the present 
paper to ascribe the problems of instability to the mechanical behaviour of the sand layers.

Several studies (Fredlund \& Rahardjio 1993, Fredlund \& Xing 1994) have highlighted that the "rock like" behaviour of partially saturated sands is caused by low water contents and consequentially by elevate suctions that might arise in such materials.

Relatively large suctions and strengths can arise in uncemented coarse-grained soils with very low water contents after the application of high compressive stress, as recently studied by Atkinson \& Nocilla (2003). In their work the application of high compressive stress was one convenient method for achieving the required suction and a metastable structure. The presence of a metastable structure is caused naturally by various geologic and geomorphologic processes and it is a prerequisite to the formation of a collapsible deposit (Dudley 1970). In this perspective the sands of Agrigento have the suitable characteristics for studies on the presence of a metastable structure on the mechanical behaviour of coarse grained soils.

\section{INSTABILITY PROCESSES}

The Valley of Temples stands on the southern limb of an asymmetrical gently sloping syncline made of calcarenitic benches and interbedded sand, sandy clay and clay of the Pleistocenic age. The northern limb is steeper than the southern and the axis is oriented towards W-NW/E-SE.

In spite of the occasional typical badlands surface configuration on the southern limb, the clay slopes exhibit a rather uniform profile. According to the stratigraphy furnished by the Parco Archeologico e Paesaggistico della Valle dei Templi di Agrigento, the blue clay, which contains grey and slightly silty sands, are offlapped by a few meters thick layer of yellow sand, which underlies an abrupt calcarenite plate about $10 \mathrm{~m}$ thick (Figs. 1, 2).

In the geological scheme by Ruggieri (1961) this plate is the III level of calcarenite. On the top of the calcarenite plate, there are: another layer of silty clay, a thin layer of marine terrace deposits and finally, a few meter thick detritic coating of continental origin.

Over the centuries, the landscape has acquired the typical geomorphological setting of cuestas, which is due, as indicated by many authors, to selective erosion, therefore a considerable undermining of the calcarenite plate has taken place. Several serious instability processes have been affecting foundation soils in the archaeological area where landslides often occur. When the instability reaches the upper slopes, the calcarenite rocks are subject to topplings (Figs. 3, 4).

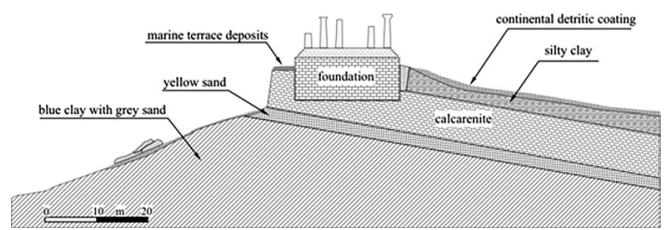

Figure 1. Stratigraphic section.

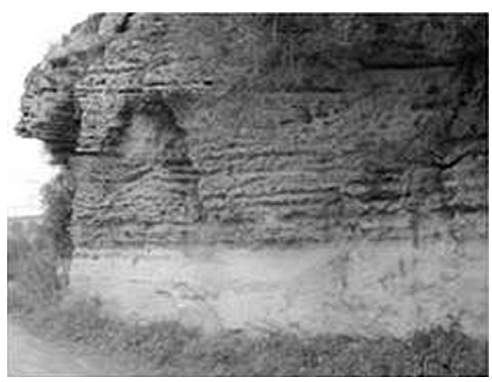

Figure 2. The sand layer and the overlying calcarenite.

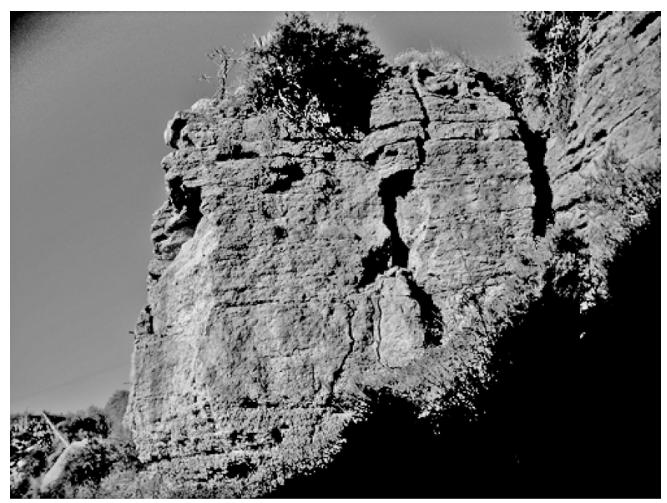

Figure 3. An incipient toppling.

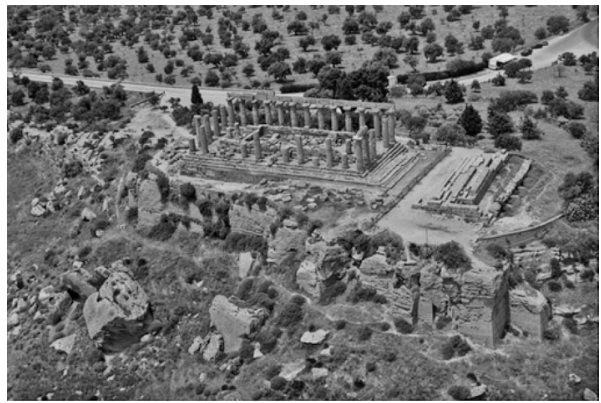

Figure 4. Aerial photo of the Temple of Hera: Note the fallen blocks and the fractured cliff face. 
This instability affects the morphology of the site, where the rock slopes are moving back.

The situation of the south-east cuesta edge is particularly interesting: the well preserved Doric temple, the Temple of Hera Lacinia, is located on its top, as shown in Figure 4.

The cliff faces of the cuesta edge are exposed towards south, aligned with the direction of the stratum, and by faces oriented towards E-NE, which is approximately the corresponding dip direction.

At the end of the nineteenth century, as referred to by Cavallari (op. cit.) and the Royal Commission records presided over by the Prince Lanza di Scalea (op. cit), it was already known that the deep foot erosion of the sand layer was coming to light again and was aggravating the condition of both the natural cliffs and the coating walls increasing the concerns for the safety of the Temple foundations. Several works aiming at improving the stability such as stone ashlars or brickwork "fillings" had been carried out in the past (Cavallari, op. cit.).

For instance, a retaining wall was built on the south side and in proximity of the SW and SE corners of the cliff where the Temple is based.

This "substructure" of supporting buttresses, as shown in Figure 5, was built taking into account a potential excess of flowing water, hence the construction of a catch-water and a drainage system situated along the back side of the retaining wall, between the Temple's basement and the cuesta edge, reinforced by further underpinning.

According to the stratighraphic section supplied by the Parco, the foundation of the temple of Hera is still an original Greek manufacture, set $6 \mathrm{~m}$ deep at most in the calcarenite bench.

As shown in Figure 6, an exploratory excavation gave access to the observation of the bare foundations, formed by large isodomum blocks, separated from debris soils with an impressive French drain,

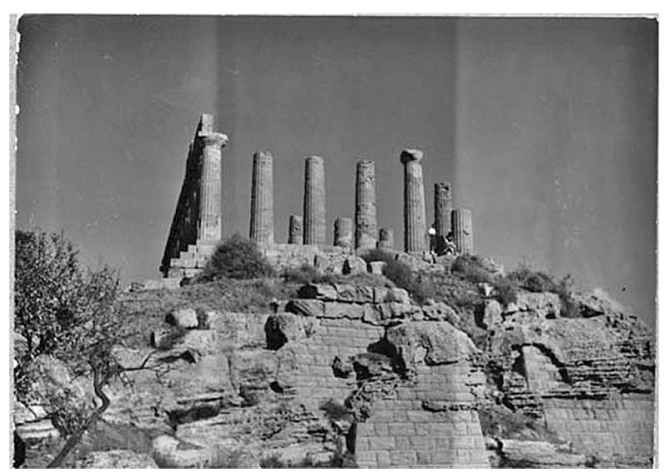

Figure 5. Old photograph showing the underlying retaining structure beneath the western cliff of the Temple.

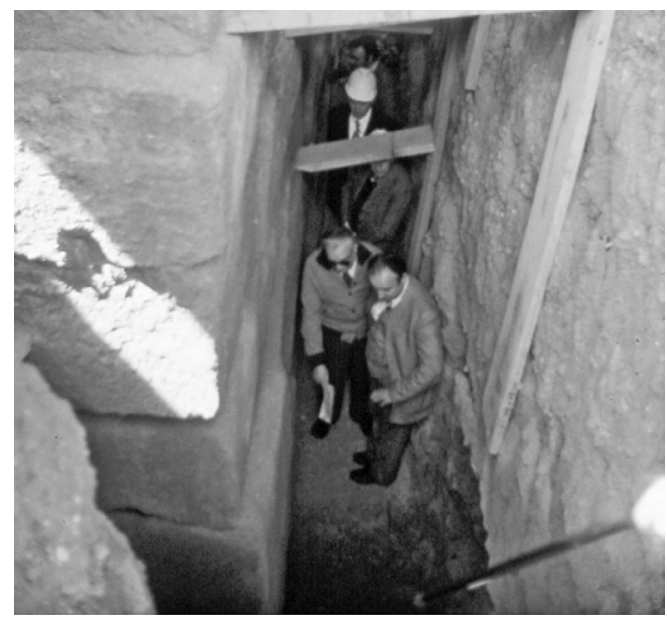

Figure 6. The Temple foundations.

which is situated all around the foundation wall and under the Temple's floor.

The study presented in this paper focuses on the $3 \mathrm{~m}$ sand layer situated underneath the Temple starting from 2 to $6 \mathrm{~m}$ below foundations.

In the area of the Temple, the groundwater table located $20 \div 25 \mathrm{~m}$ underneath the topographic surface in correspondence of the upper calcarenite plate, descends progressively along the slope until it reaches almost ground level, in proximity of the bottom of the valley.

\section{CLASSIFICATION AND PETROGRAPHIC CHARACTERIZATION}

The experimental programme and the numerical modelling have been carried out in the laboratories of the DICAAM Department of the University of Palermo and DICATAM Department of the University of Brescia.

A preliminary observation in situ revealed the presence of a sand which apparently seems a weakly cemented locked sand. Because of their consistency, an electric saw was used to take parallelepipedal samples of several cubic decimeters. The shape and the dimension of the samples have been chosen accordingly to match the standard sample packing used for mechanical testing.

The particle size distribution resulting from the tested soil revealed a fine and medium sand characterized by a quite high uniformity coefficient (Fig. 7).

As for the sand properties, the particle density is $26.47 \mathrm{kN} / \mathrm{m}^{3}$, the bulk density is $15 \mathrm{kN} / \mathrm{m}^{3}$, the porosity is between $45 \%-54 \%$ with an average value of $n_{\text {average }}=49 \%$, the degree of saturation in situ is much lower than $100 \%$, between $6 \%$ and $9 \%$. 


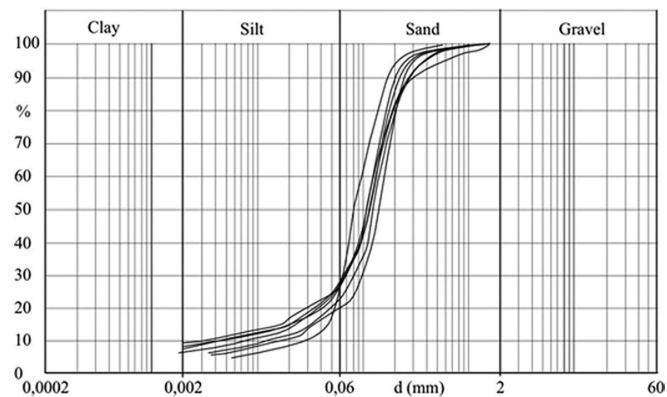

Figure 7. Particle size distribution of the analysed sands.

The slaking test provides a very low value of the durability index (Id $<50 \%)$. However, although the soil does not present neither the typical low porosity of dense sands nor the typical values of the durability index of the weakly cemented sands, the consistency of this soil and its ability to be moulded indicates non-zero values of strength that seem to be caused by the high values of negative superficial stresses between grains, resulting from the reduced water content.

The textural and petrographic characterisation of the sands has been performed by means of the observation of four thin sections in transmitted light (Fig. 8).

According to Zimbardo et al. (2011), the pores can be classified as macropores when their size is a multiple of the modal size of the grains, mesopores when they have about the same size of the modal size of the grains, and micropores when the size is lower than the modal size of the grains or like the smallest grains.

The soil fabric of the present case study can be described as a sponge type (lithotype B), with the area of all macropores much smaller than the mesopores.

Although the intraparticle pores contribution to the total porosity is very high, an amount of these pores (less than $10 \%$ of the total porosity) are close and not destroyable during saturation or mechanical tests. For this reason, the interparticles pores, in spite of their low amount, have a bigger impact on "collapsibility".

The composition of clasts is rather uniform. In more detail the clasts are made of quartz, fragments of mollusca shells, foraminifera and plates of echinoderms, algal micrite and microsparite. The relative abundance of each type of clasts is variable. As shown in the thin section of Figure 8 two irregular areas are detectable: the A area, where quartz clasts prevail and the B area, where bioclasts prevail. As for the quartzose clasts, they are generally composed by monocrystalline grains. Composition percentages are listed in detail in Table 1.

As for the particle size distribution, the quartz grain dimensions are between $25-500 \mu \mathrm{m}$, with a

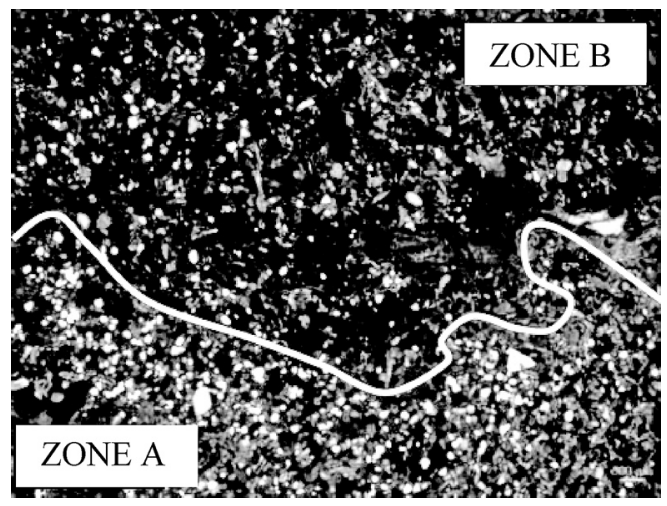

Figure 8. Thin section ( $7 \mathrm{x}$ magnification, cross polarized light) and relative composition of zones $\mathrm{A}$ and $\mathrm{B}$.

Table 1. Composition of zones A and B.

\begin{tabular}{lll}
\hline Composition & A & B \\
\hline Quartz & $50 \%$ & $30 \%$ \\
Bioclasts & $20 \%$ & $55 \%$ \\
Micrite microsparite & $20 \%$ & $55 \%$ \\
\hline
\end{tabular}

modal value of $130 \mu \mathrm{m}$; the dimensions of fragments of mollusca shells and foraminifera exoscheletons are between $100-600 \mu \mathrm{m}$; the micrite grain dimensions are between $80-230 \mu \mathrm{m}$; the microsparite grain dimensions are between 130 $260 \mu \mathrm{m}$ and the dimensions of the plates of echinoderm are about $320 \mu \mathrm{m}$. Only as much as $0,5 \%$ of both quartz and microsparite grains have dimensions bigger than $500 \mu \mathrm{m}$. Fragments of fossils of $900 \mu \mathrm{m}$ are also present.

Roundness is low in most cases. Sphericity is variable. The grain contacts are of flat type or concave-convex and tangential type, with a predominance of flat contacts. However, the presence of pelitic and silty coats that cover grains often prevent their direct contact (Fig. 9).

The presence of particles of such a nature aroused special interest. In the literature regarding the mechanical behaviour of partially saturated soils (Collins \& Mc Gown 1974, Alonso et al., 1987), the presence of these kind of particles is considered of fundamental importance because, together with the type of grain contacts and pore geometry, it affects the way in which water wraps solid particles (Kezdi 1974) and the continuity, distribution and interaction among solid, liquid and gaseous phases in the material (Wroth \& Houlsby 1985).

Hence, it affects the presence and the intensity of suction forces resulting from the presence of menisci. 


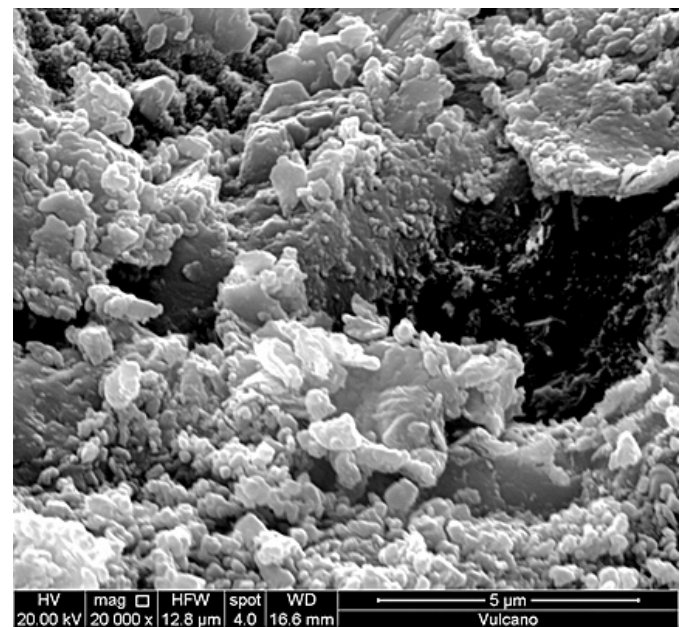

Figure 9. SEM photograph: Tabular silty particle aggregates are present (see lighter zones).

According to the classification suggested by the aforementioned authors, the sand layer considered in this paper can be included in a class of soils with a continuous gaseous phase ad a discontinuous liquid phase. This condition is typical of natural soils, common in dry areas where the degree of saturation is very low $(\mathrm{S}<<100 \%)$.

According to many authors (Barden et al., 1973, Clemence \& Finbarr 1981, Rogers 1995) bonding mechanisms in collapsible soil can be classified in three main types: by capillarity or matric suction forces, clay and silty particles at coarser particle contacts and cementing agents such as carbonates and oxides. According to the durability test results obtained on the investigated sand, the bonding mechanism seems to be able to be attributed only to capillarity or matric suction forces. Although fabric lacks a simple quantitative descriptor (Alonso 1993 as cited by Pereira \& Fredlund 2000) it is widely recognised as important in explaining collapse behaviour. In order to ensure realistic assessments about the mechanical behaviour of this sand, the nature of weak connectors (the coating pelitic and silty particles) present will be investigated in future research together with their mineralogical nature.

\section{MECHANICAL CHARACTERIZATION}

The testing programme consisted of 8 direct shear and 3 oedometer tests. Direct shear tests have been carried out under 8 different vertical loads, from $25 \mathrm{kPa}$ to $300 \mathrm{kPa}$, as shown in Figure 10 . The direct shear tests have been performed with a non-standard procedure: samples have been set up and initially loaded for a period of 24 hours at their natural water content. Very low values of the natural water content $\left(1,8 \%<\mathrm{w}_{\mathrm{N}}<3 \%\right)$ and a degree of saturation between $6 \%$ and $9 \%$ have been detected.

After the initial 24 hours, samples have been flooded and wetted at a constant load for additional 24 hours. As a last stage, standard shear tests have been carried out.

Regarding the oedometer tests, samples have been consolidated under vertical load at a natural water content below 3\%. In correspondence of 3 different vertical stresses, respectively of $1.54 \mathrm{MPa}$, 3.22 $\mathrm{MPa}$ and 7.26 MPa, the three samples have been flooded and wetted.

After settlement completion, a new step of load has been applied. Settlements caused by each load have been recorded by the displacement transducer.

During the direct shear tests, a particular attention was required when applying vertical stresses, before and after cell flooding and the consequential sample wetting. A vertical strain occurs rapidly after wetting and, even in the case of low vertical applied stresses, it can reach the $1 \%$ of the initial sample thickness in few minutes. This percentage tends to increase with the increasing of the applied vertical stress. In Figure 10 experimental values of the void indexes variations $(\Delta \mathrm{e})$ for different values of normal applied stress $\left(\sigma_{n}\right)$, after cell flooding are shown and the equation of the best-fit line presented. In the same diagram, labels with degree of saturation values at the beginning and at the end of each test show that the final degree of saturation is always lower than $100 \%$ after the flooding of the cell. The water content increases but never saturates samples completely.

As for the oedometer tests, in Figure 11, the void ratio against the vertical applied load has been plotted and the vertical stress corresponding to the cell flooding and sample wetting has been highlighted.

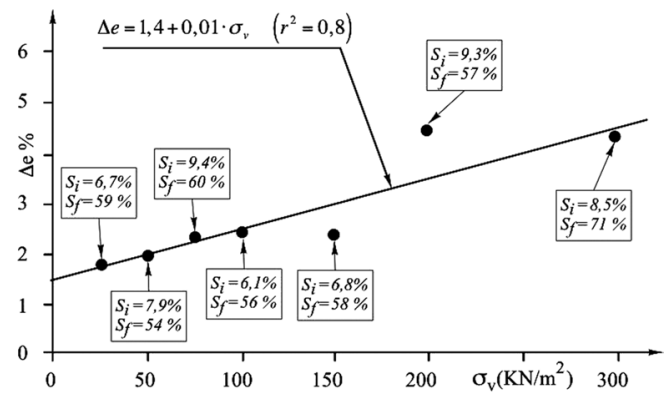

Figure 10. Quick variations of void indexes $(\Delta \mathrm{e})$ for different values of normal applied stress, after cell flooding. 


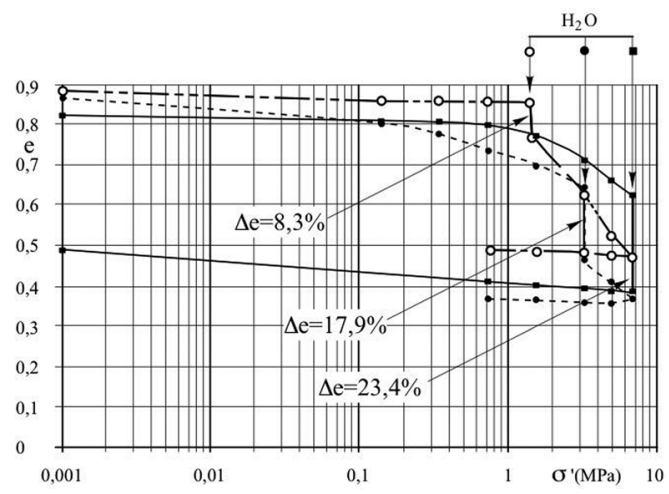

Figure 11. Compression paths during oedometer tests.

Accordingly to the illustrated compression paths, quick settlement with increasing intensity occurs when the flooding is applied in correspondence of the given vertical stress. When the unloading is applied, the irreversibility of the compression is evident: this is due to the structural "collapse", resulting from the erasing of the suction forces. These suction forces have a "structural" role (Kavvedas 2000), which is comparable to weak cementation or to grain locking for those material for which, if a collapse occurs, a fabric destruction is identified similarly to what described by Gens et al. in 1995.

Similar collapse phenomena, caused by wetting of the material, have been observed in Aeolian fine sand deposits in South Africa (Jennings 1965) or Naples volcanic tuff (Feola et al., 2004, Evangelista et al., 2004).

In conclusion, two separate settlement developments have been observed respectively during the two phases: a first phase of the test carried out on samples at their natural water content, and a second phase conducted after wetting. The two recognizable compression paths are separated by the quick settlement, which corresponds to the collapse originated by the wetting phase. According to these results, the artificial wetting of the soil is clearly unable to erase completely the suction forces of menisci, similarly to what occurs in natural soils after a rainfall, no matter how intense. Residual suctions guarantee non-zero strength even in presence of elevate and irreversible strains.

\section{THE MODELLING PROCESS}

In order to perform the stability and safety analysis, a modelling process has been carried out for the site under investigation. Although a more sophisticated analysis involving a more complex partially saturated soil characterization is advisable, at this level of the research, a simple Mohr-Columb strength failure criterion has been considered appropriate and the numerical analysis has been carried out in a plane deformation state using the finite element program Plaxis, once defining and quantifying the geometry of the boundary value problem under investigation.

The foundation soil section consists of an $8 \mathrm{~m}$ thick layer of calcarenite overlying a $3 \mathrm{~m}$ thick stratum of sand, situated over the clayey deposit. The above assumptions, although simplified, allow a first understanding of the essential elements of the mechanical behaviour of this case study.

Figure 12 also illustrates the mechanical parameters obtained from the experimental tests on the sand and successively used in the model. Regarding the clay deposit and the layer of calcarenite parameters, labels with values are also reported. The values have been obtained from the literature review and from previous research studies. In detail, Musso \& Jappelli (1980) and Croce et al. (1969) reports provided the values of clay parameters and Evangelista \& Pellegrino (1990) the values of calcarenite parameters. After determining the initial stress state resulting from the stratigraphic sequence shown in Figure 1, the changes in stress states have been calculated.

Changes in stresses have been estimated considering the partial destructuration of sands, resulting from the increased natural water content only.

The increment in the degree of saturation in sands is due to the permeability deriving both from calcarenite porosity and from the subvertical discontinuities in the calcarenite stratum.

Along the crest of the calcarenite cuesta, all around the temple, discontinuities have a spacing of 4-5 $\mathrm{m}$ so that, in the modelling process, the quick strain which occurs in sands after wetting, has been taken into account in two different analyses: the first in which the sand strains occur for $5 \mathrm{~m}$ from the cuesta edge, and the second for which strains occur for $10 \mathrm{~m}$ from the same edge. In this first phase of the analysis the vertical contact stresses between the sand layer and the calcarenite cuesta have been

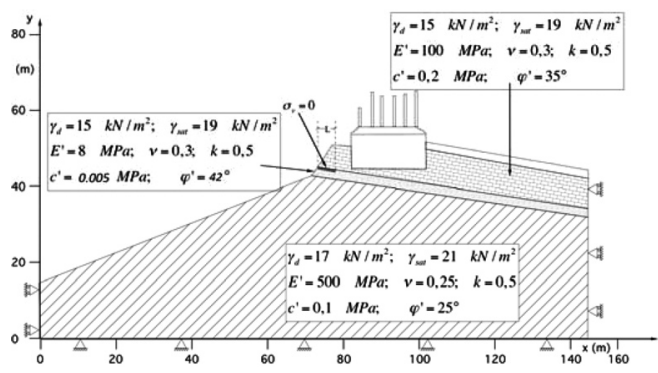

Figure 12. Geometry of the boundary value problem under investigation. 
considered equal to zero. In other words, a condition hardly reachable in reality has been simulated in order to perform the sand layer settlement according to the laboratory test results. A lithostatic initial stress state and a value of 0.5 coefficient of earth pressure at-rest have been chosen by the authors: shear stress contours are illustrated in Figure 13a. It is worth noticing that, in uncemented soil, the volume change associated with "collapse" is confined to the wetted zone (Fredlund \& Gan 1995). Hence, two simulations corresponding to different saturation conditions of sand have been performed (Figs. 13b, 13c). The two analyses highlight the change in stress states with the inwards progression of the wetting of the sand. In the first case $(\mathrm{L}=5 \mathrm{~m})$, the ratio between the mobilised shear strength to the available shear strength tends to unity in the wetted zone. In the second case $(\mathrm{L}=10 \mathrm{~m})$ in accordance to the extension of how much the wetting process has moved inwards, this ratio remains below the unity and the safety conditions are improved, if tensile stresses that might cause plastic points in the calcarenite cuesta are not considered. The analyses illustrated in Figure $14 \mathrm{a}$, for the $\mathrm{L}=5 \mathrm{~m}$ case and in Figure 14b,
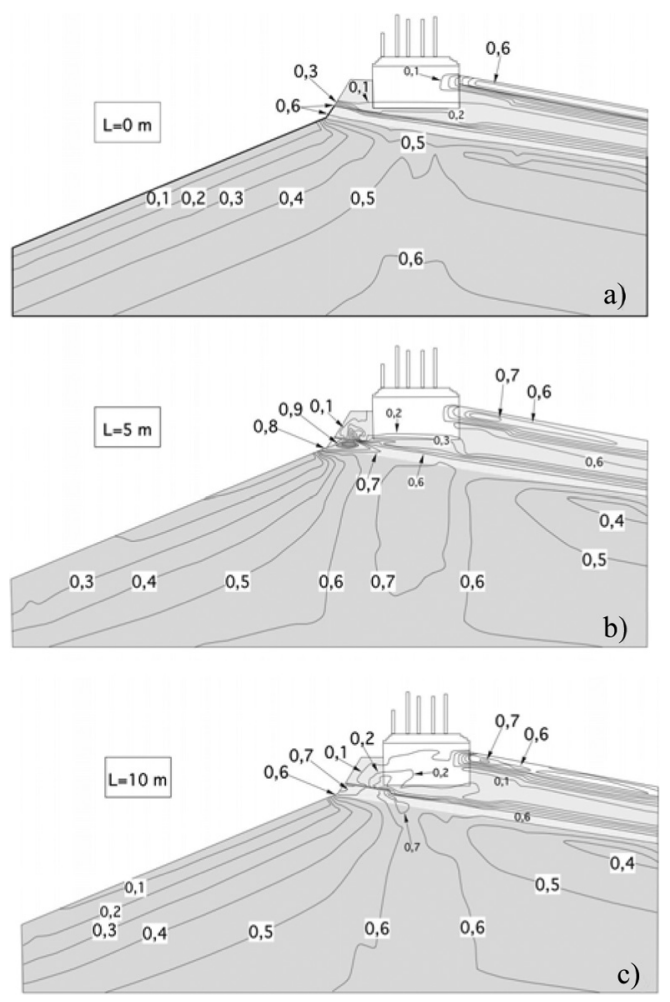

Figure 13. Relative shear stress contours in a) Lithostatic state, sand at the natural water content b) Wetted sand zone $5 \mathrm{~m}$ long c) Wetted sand zone $10 \mathrm{~m}$ long.
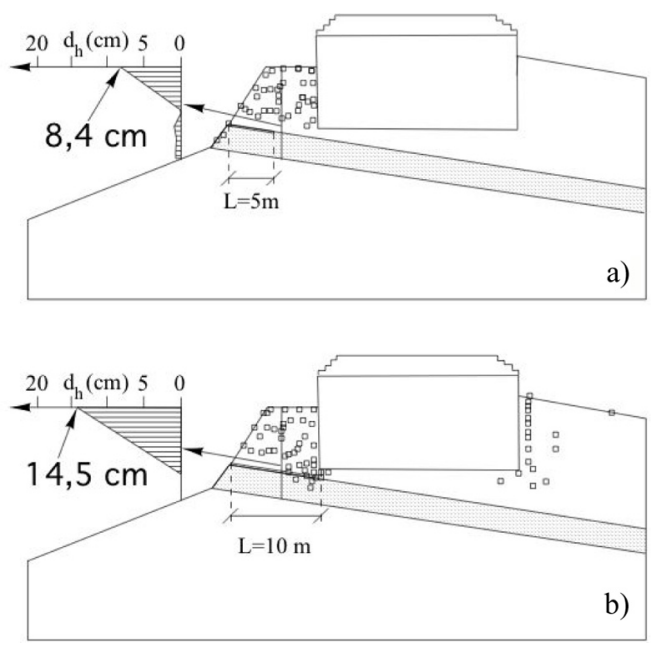

Figure 14. Plastic points and horizontal displacements $\mathrm{d}_{\mathrm{h}}$ for a) Wetted sand zone $5 \mathrm{~m}$ long $\mathrm{b}$ ) Wetted sand zone $10 \mathrm{~m}$ long.

for the $L=10 \mathrm{~m}$ case, pinpoints the following: plastic points might occur in the calcarenite cuesta in both cases, resulting from tensile stress states, which might also arise on the right of the Temple for $\mathrm{L}=10 \mathrm{~m}$ (Fig. 14b). Figures 14 include horizontal displacements in the vertical section comprehensive of both the sand and the calcarenite layer.

As highlighted, displacements can reach the value of $10 \mathrm{~cm}$ and more: this result, together with what previously detected about the destructuration process of sands, indicates that toppling failures might arise in the calcarenite cuesta. Summarising, at the top of the calcarenite cuesta, displacements, which are decreasing in depth towards the contact with the underlying sands, might occur as typical in toppling movements. As a result of this background, the subvertical discontinuities in the calcarenite cuesta might be connected to the deformation mechanisms in the sand layer and in the underlying clay deposit and not only to the uplift phenomena, as reported by several authors so far.

\section{CONCLUSIONS}

The behaviour of the investigated sand has been recognized by the authors of the paper as typical of collapsible soils of which an essential requirement is that an open metastable structure develops through bonding mechanisms. To achieve this open structure, bonding between particles or grains of sufficient strength must occur which, when weakened by the addition of water, allows particles 
to slide over one another, resulting in collapse. According to the durability test results obtained on the investigated sand, the bonding mechanism seems to be able to be attributed only to capillarity or matric suction forces. In order to ensure realistic assessments about the mechanical behaviour of this sand, the nature of the weak connectors present will be further investigated.

The direct shear and the oedometer test experimental results during consolidation show that vertical strains occur rapidly after wetting and that, even with low vertical applied stresses, the settlement can reach the $1 \%$ of the initial sample thickness in few minutes under constant load. Settlements occur because of the suction stresses reduction after flooding. These suction forces have a "structural" role. The volume reduction progressively increases with the increasing of the external applied stress. In the in situ calcarenite, the primary permeability and, above all, the presence of subvertical discontinuities, allow elevate amount of water to flow in the case of high intensity rainfall phenomena. As a consequence, an important increment of the water content takes place in the underlying sand layer, which usually has a very low degree of saturation. Although the full saturation is not reached, the suction stresses decrease and a structural settlement occurs.

As indicated by many authors, the geomorphological landscape evolution has been attributed to a considerable undermining of the calcarenite, in which sands participated because of their aptitude to Aeolic erosion and splash erosion only.

The present study introduces sand collapse, resulting from the suction stress reductions, as the main cause of the toppling failures that might arise in the calcarenite cuesta, where the subvertical discontinuities might keep on developing. As highlighted by the numerical analyses, further instability phenomena might arise because of the plastic conditions, due to tensile stresses, reached in the sand layer and in the calcarenite bench.

In the sand layer, the plastic strain accumulation, can be a contributory to its elevate aptitude to erosion, the more so since the erosion occurs even in areas protected by vegetation, which mitigate the wind and splash erosion impacts. What kind of role deeper sand layers situated in the deeper clay deposit might have had in the instability phenomena of the past and in the slope stability in general, still needs clarification. In this far from encouraging context a monitoring of the instability processes in relation to sand decay is of the upmost importance and presently being scheduled be the Ente Parco Archeologico e Paesaggistico della Valle dei Templi in charge of monitoring the stability of the temples since decades.

\section{ACKNOWLEDGEMENT}

The authors are grateful to Prof. ssa M. Santamaria and to Ing. F. Di Franco for scanning electron microscope.

\section{REFERENCES}

Alonso E.E., Gens A., Hight D.W. 1987. Special problem soils. General Report. In: Proc 9th Eur Conf on Soil Mechanics and Foundation Engineering, Dublin, Ireland 3:1087-1146.

Atkinson J., Nocilla A. 2003. Suction and strength in heavily compressed carbonate sand. 2003 Géotechnique 53, no. 9, 831-832.

Barden L., McGown A., Collins, K. 1973. The collapse mechanism in partly saturated soil. Engineering Geology, 7, 49-60.

Cavallari C. 1883. Rapporto dell'Ing. topografo Cristoforo Cavallari sui Danni avvenuti al muro di sostegno della strada di accesso al Tempio di Giunone Lacinia e visita alle antichità di Girgenti, in data 19genn. E 30 apr., Archivio centr. dello Stato, II vers, II serie, busta 147 fasc. 1713.

Clemence S.P., Finbarr A.O. 1981. Design considerations for collapsible soils. Journal of Geotechnical Engineering, 107(3), 305-317.

Collins K., McGown A. 1974. The form and function of microfabric features in a variety of natural soils. Géotechnique, Volume 24, Issue 2, pages 223-254

Cotecchia V., D'Ecclesiis G., Polemio M. 1995. La dinamica dei versanti della Valle dei Templi di Agrigento. Geologia applicata e idrogeologia Bari, volume XX - parte I.

Cotecchia V. 1996. Geotechnical degradation of the archaelogical site of Agrigento. Arrigo Croce memorial Symposium, Balkema.

Croce A., Jappelli R., Pellegrino A., Viggiani C. 1969. Compressibity and strength of stiff intact clays. Proc. VII Int. Conf.on Soil Mechanics and Foundation Engineering, Mexico City.

Croce A., De Miro E., Fenelli G.B., Jappelli R., Liguori V., Morandi R., Nocilla N., Pace E., Pellegrino A., Rossi Doria P. 1980. La Città di Agrigento e la Valle dei Templi. Questioni di stabilità del territorio e di conservazione dei monumenti XIV Conv. Naz. di Geotecnica.

Dudley, J.H. 1970. Review of collapsing soils. Journal of Soil Mechanics and Foundation Division, ASCE, 96(3), 925-947.

Evangelista, A., Pellegrino, A. 1990. Caratteristiche geotecniche di alcune rocce tenere italiane. Le rocce tenere: terzo ciclo di conferenze di meccanica e ingegneria delle rocce.

Evangelista A., Nicotera M.V., Aversa S. 2004. Un'apparecchiatura di taglio a suzione controllata per lo studio delle condizioni di innesco dei fenomeni franosi nelle coltri piroclastiche, XXII Convegno Nazionale di Geotecnica, Palermo 22-24 settembre 2004.

Feola A., Lombardi G., Pellegrino A., Viggiani C. 2004. I dissesti di Via Settembrini a Napoli a seguito dell'evento piovoso del 15 settembre 2001. XXII Convegno Nazionale di Geotecnica, Palermo 22-24 settembre 2004. 
Fredlund D.G., Rahardjo H. 1993. Soil mechanics for unsutered soils. Wiley and Sons, Toronto.

Fredlund D.G., Xing A. 1994. Equation for the soil water characteristic curve. Can. Geotech. J. 31, 3.

Fredlund D.G., Gan J.K.M. 1995. The collapse mechanism of a soil subjected to one-dimensional loading and wetting. In Proceedings of NATO Advance Workshop on Genesis and Properties of Collapsible Soils (eds Derbyshire, E., Dijkstra, T. and Smalley, I.J.). Loughborough, April 1994, pp. 173-205.

Gens, A., Alonso E.E., Suriol J., Lloret A. 1995. Effect of structure on the volumetric behavior of a compacted soil. Proc. 1st Int. Conf on Unsatured soil. NSAT97. Alonso, Delage eds. Paris.

Lanza Di Scalea F. 1883. Verbali della Commissione per la conservazione e i restauri delle antichità agrigentine 11, 12 e 17 ott, Archivio centr. dello Stato, II vers, II serie, busta 147 fasc. 1713 .

Jennings J.E. 1965. Theory and practice of construction on partly satured soils as applied to South African conditions. Proc. Int. Conf. expansive Clay Soil. Texas A.M. Press.

Kavvadas M.J. 2000. Modelling the soil behaviourSelection of soil parameters. The Geotechnics of Hard Soils-Soft Rocks-Balkema, Rotterdam.

Kézdi A. 1974. Handbook of soil Mechanics-Soil physics, Elsevier Amsterdam, Oxford, New York.

Musso A., Jappelli R. 1980. Indagini relative al movimento franoso del Dicembre 1976 che ha interessato la Valle dei Templi di Agrigento. Rapporto di ricerca ex istituto di geotecnica e arte mineraria dell'Università di Palermo.

Musso A., Ercoli L., 1988. Monuments and landslides in the Agrigento Valley. Proc. Int. Symp. IAEG The engineering geology of ancient works, monuments and historical sites. Balkema ed.

Pereira, J.H.F., Fredlund, D.G. 2000. Volume change behaviour of collapsible compacted gneiss soil. Journal of Geotechnical and Geoenvironmental Engineering, 126(10), 907-916.

Rogers, D.D.F. 1995. Types and distribution of collapsible soils. In Proceeding of NATO Advance Workshop on Genesis and Properties of Collapsible Soils (eds Derbyshire, E., Dijkstra, T. and Smalley, I.J.). Loughborough, April 1994, pp. 1-17.

Ruggeri G. 1961. Commenti ad una recente nota sul Pliocene in Sicilia. Rivista Mineraria Siciliana $\mathrm{n}^{\circ} 70-71$.

Wroth, C.P., Houlsby G.T. 1985. Soil mechanics: property characterization and analysis procedure.

Zimbardo M., Nocilla N., Ercoli L. 2011. Petrographic and textural characteristics and mechanical behaviour of Sicilian calcarenites. Proceedings of the 15th European Conference on Soil Mechanics and Geotechnical Engineering (geotechnics of hard soils/soft rocks). A. Anagnostopoulos al. (Eds.) 